\title{
Distribution and dispersal of two invasive crayfish species in the Drava River basin, Croatia
}

\author{
S. Hudina ${ }^{(1)}$, M. Faller(2) A. Lucić(1), G. Klobučar( ${ }^{(1)}$, I. Maguire ${ }^{(1)}$
}

Received September 29, 2009 / Reçu le 29 septembre 2009

Revised December 10, 2009 / Révisé le 10 décembre 2009

Accepted December 11, 2009 / Accepté le 11 décembre 2009

Key-words: non-indigenous crayfish species, dispersal rate, impact

\section{ABSTRACT}

The aim of this work is to explore the current distribution and dispersal rates of two nonindigenous crayfish species (NICS) recorded in Croatia: the signal crayfish (Pacifastacus leniusculus) and spiny-cheek crayfish (Orconectes limosus). Both NICS have been recorded in the Drava River basin, with signal crayfish spreading downstream from the north-west along the Drava's tributary the Mura River, and spiny-cheek crayfish spreading upstream from the east from the Danube River throughout the Drava River. Signal crayfish distribution in the Mura River has been recorded up to $3 \mathrm{~km}$ from the confluence with the Drava River. Based on literature data and the current recorded distribution front, the downstream dispersal rate was between 18 and $24.4 \mathrm{~km} \cdot \mathrm{yr}^{-1}$. Spiny-cheek crayfish distribution has been recorded $15 \mathrm{~km}$ upstream of the Drava River mouth into the Danube River. Its upstream dispersal in the Drava River has been calculated at $2.5 \mathrm{~km} \cdot \mathrm{yr}^{-1}$. Both NICS could have an impact on native crayfish populations recorded within the Drava River basin in Croatia: the noble crayfish (Astacus astacus) and the narrow-clawed crayfish (Astacus leptodactylus). In the Mura River no noble crayfish have been recorded since 2007 , and the watercourse is at the moment dominated by the signal crayfish. Spiny-cheek crayfish populations have been found in coexistence with narrow-clawed crayfish populations, with $O$. limosus dominating by $16: 1$.

\section{RÉSUMÉ}

Distribution et dispersion de deux espèces d'écrevisses invasives dans le bassin de la rivière Drava

\section{Mots-clés : espèces non-indigènes d'écrevisse, taux de dispersion, impact}

\begin{abstract}
Le but de ce travail est d'explorer la distribution actuelle et les taux de dispersion de deux espèces d'écrevisses non indigènes (NICS) rencontrées en Croatie : l'écrevisse signal (Pacifastacus leniusculus) et l'écrevisse américaine (Orconectes limosus). Ces deux NICS ont été rencontrées dans le bassin de la rivière Drava, l'écrevisse signal se dispersant vers l'aval depuis le nord-ouest le long de la rivière Mura affluent de la Drava, et l'écrevisse américaine vers l'amont depuis l'est et le Danube dans la rivière Drava. La distribution de l'écrevisse signal dans la rivière Mura a été enregistrée jusqu'à $3 \mathrm{~km}$ de la confluence avec la rivière Drava. D'après
\end{abstract}

(1) University of Zagreb, Faculty of Science, Department of Zoology, Rooseveltov trg 6, 10000 Zagreb, Croatia, shudina@zg.biol.pmf.hr

(2) NGO BioShock, K. Krešimira 32a, 34000 Požega, Croatia 
les données de la littérature et le front de répartition observé ici, la vitesse de dispersion vers l'aval est de 18 à 24,4 km·an ${ }^{-1}$. L'écrevisse américaine est présente à $15 \mathrm{~km}$ en amont de l'embouchure de la rivière Drava dans le Danube. Sa dispersion vers l'amont dans la rivière Drava est estimée à $2,5 \mathrm{~km} \cdot \mathrm{an}^{-1}$. Ces deux NICS peuvent avoir un impact sur les populations d'écrevisses indigènes présentes dans le bassin de la rivière Drava en Croatie : l'écrevisse à pattes rouges (Astacus astacus) et l'écrevisse à pattes grêles (Astacus leptodactylus). Dans la rivière Mura, aucune écrevisse à pattes rouges n'a été vue depuis 2007 et l'écrevisse signal prédomine dans le cours d'eau aujourd'hui. Les populations d'écrevisse américaine sont trouvées en cohabitation avec les populations d'écrevisse à pattes grêles avec O. limosus dominant dans un rapport de 16:1.

\section{INTRODUCTION}

Biological invasions are well recognized as one of the most significant components of humaninduced environmental change (Sala et al., 2000), with invasive alien species (IAS) considered the second leading factor of biodiversity loss, after habitat destruction (Lodge et al., 2000). Inland waters are especially vulnerable to biological invasions as they are subject to extensive and growing unintentional and intentional releases of organisms (Lodge et al., 1998; Ricciardi, 2001). The vulnerability of inland waters to biological invasions can result in complete domination of waterscapes in certain regions by IAS, such as water hyacinth or the red swamp crayfish (Procambarus clarkii) in several water bodies of southern Europe (Holdich and Pöckl, 2007).

Throughout history, various crayfish species have often been introduced outside their native ranges. According to Hobbs et al. (1989), transcontinental or interstate translocations include a relatively small number of crayfish species (around 20), but a large number of introductions. The introduction and cultivation of non-indigenous freshwater crayfish in Europe is increasing, so today the majority of European countries have at least one NICS introduced (Holdich, 2002).

NICS spread has a devastating impact on populations of indigenous crayfish species (ICS), which disappear in the contact zones, mainly as a consequence of crayfish plague and competition (e.g. Pöckl, 1999; Machino et al., 2004). Crayfish represent important components of freshwater food webs, both in terms of biomass and ecosystem functioning, due to their large size and relatively long life span, omnivorous feeding habits, and their role in ecosystem engineering (Lodge et al., 1994; Usio and Townsend, 2002; Statzner et al., 2003). Therefore, non-indigenous crayfish can have a profound impact on the ecosystem they invade.

As of 2008, six freshwater crayfish species are known to exist in Croatia: four native and two non-indigenous crayfish species. Three out of four native species, namely the noble crayfish (Astacus astacus), the stone crayfish (Austropotamobius torrentium) and the whiteclawed crayfish (Austropotamobius pallipes) are protected at national and international levels (Narodne novine 70/05 and 139/08; Bern Convention Appendix III). Appendix III of the Bern convention lists $A$. torrentium and $A$. pallipes as species that require the setting up of special areas of conservation for their protection (Souty-Grosset et al., 2006). Of the invasive crayfish species, spiny-cheek crayfish (Orconectes limosus) and signal crayfish (Pacifastacus leniusculus) are known to be present in Croatia. Both species were recorded in the rivers belonging to the Black Sea drainage system (Maguire and Klobučar, 2003; Maguire and Gottstein-Matočec, 2004; Maguire et al., 2008). Specifically, both NICS were recorded in the Drava River basin in Croatia, with signal crayfish spreading downstream from the north-west along Drava's tributary, the Mura River, and spiny-cheek crayfish spreading upstream from the south-east from the Drava River mouth near Osijek in addition to its downstream dispersal through the Danube River.

The aim of this work is to explore the current distribution of the two invasive species, and to estimate their dispersal speed, based on recent fieldwork and literature data. Estimation of 
dispersal includes the estimation of encounter area and encounter time of the signal crayfish and the spiny-cheek crayfish within the Drava River. These data constitute important information for any future invasive species management activities.

\section{MATERIALS AND METHODS}

\section{$>$ STUDY AREA}

The Drava River is the fourth largest and longest tributary of the Danube River. Its source is located in Italy, from where it drains the Southern side of the Alps to the Danube River and the Black Sea. This 719-km-long river flows through Austria, Slovenia, Croatia and Hungary. Between the two latter countries (Croatia and Hungary), it forms the border, while its mouth into the Danube River is located in Croatia near Osijek. The Mura River is a tributary of the Drava, and subsequently the Danube. Its total length is $465 \mathrm{~km}$, of which $295 \mathrm{~km}$ is located in Austria, $98 \mathrm{~km}$ is in Slovenia and the rest forms the border between Croatia and Hungary (75 km).

The Drava River has been severely impacted by the construction of hydropower plants. Along the upper reaches, above the Donja Dubrava impoundment in Croatia (up to rkm 254), more than 20 dams have been constructed. Also, as in the majority of European rivers, the lower Drava reaches have been considerably regulated with embankments and channels. In spite of these changes, natural habitats along the middle and lower reaches of the river host unique assemblages, as well as several endemic species, of flora and fauna. Therefore, initiatives have been taken to establish a Transboundary Biosphere Reserve (WWF, 2009) along the Drava, the Danube and the Mura rivers involving all countries sharing the river basin.

In the Drava River basin in Croatia two native crayfish species have been recorded: the noble crayfish ( $A$. astacus) and the narrow-clawed crayfish (A. leptodactylus) (Maguire and Gottstein-Matočec, 2004). The noble crayfish populations are more numerous in the upper reaches of the Drava River in Croatia, while the narrow-clawed crayfish occurs in the lower reaches near its confluence with the Danube River.

\section{$>$ RESEARCH METHODS}

Research comprised of literature and fieldwork data gathering. Literature data gathering included data from neighboring countries in the region, namely Slovenia, Serbia and Hungary (Pöckl, 1999; Bertok et al., 2003; Puky et al., 2005; Govedič, 2006; Govedič et al., 2007; Pavlovič et al., 2006; Puky and Schád, 2006; Veenvliet, 2006), as the presence of NICS in Croatia is mainly the consequence of their dispersal through large rivers of the region.

Fieldwork was performed along the Drava River catchment from September 2007 to August 2009. Sampling encompassed the rivers Drava and Mura, their small tributaries and side channels, as well as nearby ponds. Altogether, 160 sites in the Mura River were analyzed, 46 sites in the Drava River, 10 sites in the Danube River, 4 channels adjacent to these rivers and 2 ponds (Table I).

Sampling consisted of hand search and the use of baited LiNi traps (Westman et al., 1978). In the Danube, the Drava and the Mura rivers and their adjacent channels and ponds, traps were exposed along the shore. Additionally, some sampling in the Drava River was performed by exposing traps in the middle of the watercourse. LiNi traps were positioned from the boat (three sampling occasions on the Mura River, three sampling occasions on the Drava River) or from the shore. During fieldwork by boat, traps were exposed at approximately $250-\mathrm{m}$ intervals and left overnight. During the fieldwork from the land, traps were set more densely at approximately 25-m intervals and examined for 1-4 nights. All captured NICS were sexed, weighed, their morphometrical characteristics measured and taken to the laboratory for further analyses. Native species were sexed, weighed and measured and released at the same location where they were caught.

Graphical presentations of species distribution range were done using ArcGIS 9.1 software. 
Table I

Examined localities and number of sampled sites.

Tableau I

Les localités étudiées et le nombre de sites échantillonnés.

\begin{tabular}{|l|c|c|}
\hline Watercourse/Locality & Type & No. of examined sites \\
\hline Mura & River & 160 \\
\hline Trnava & Channel & 1 \\
\hline Palinovec & Pond & 1 \\
\hline Goričan & Pond & 1 \\
\hline Drava & River & 46 \\
\hline Renovo & Channel & Entire channel \\
\hline Drava Otok & Old meander & 1 \\
\hline Donja Dubrava & Channel & 1 \\
\hline Danube & River & 10 \\
\hline
\end{tabular}

\section{RESULTS}

\section{> SPINY-CHEEK CRAYFISH (ORCONECTES LIMOSUS)}

O. limosus was first recorded in Croatia in 2003 (Maguire and Klobučar, 2003; Maguire and Gottstein-Matočec, 2004) in the Nature Park Kopački rit, where it spread from the Hungarian section of the Danube River. Since 2003 it has been found at several sites along the Danube River and its tributaries or adjacent channels (Figure 1). The presence of $O$. limosus in the Hungarian and Serbian parts of the Danube River was confirmed in several studies (Karaman and Machino, 2004; Puky et al., 2005; Pavlovič et al., 2006; Puky and Schad, 2006), some of which have emphasized the fast colonization rate of this species in its downstream migration along the Danube River (13-16 km·. $\mathrm{r}^{-1}$; Puky and Schad, 2006).

In Serbia, the spiny-cheek crayfish was recorded in 2002 in the Danube River near Apatin, which is only $10 \mathrm{~km}$ upstream of the locality of the first record in Croatia. In 2003, it was found near the town of Novi Sad (Serbia), around $130 \mathrm{~km}$ downstream of the first record site in Croatia (Karaman and Machino, 2004). In Romania, the most downstream record (year 2008 ) is the locality Berzasca, while in the leşelniţa locality (961 rkm) only A. leptodactylus was found (Pârvulescu et al., 2009). Additionally, spiny-cheek crayfish has been found in the Tisza River and its tributaries (Sallai and Puky, 2008 cited in Pârvulescu et al., 2009), meaning that invasion has spread to additional large river systems. When all distribution data are taken into account, the average speed of the downstream spread is $50 \mathrm{~km} \cdot \mathrm{yr}^{-1}$, while the overall dispersal speed between Budapest and Berzasca is $30 \mathrm{~km} \cdot \mathrm{yr}^{-1}$ (Table II). On average, the downstream dispersal rate is lowest in Hungary $\left(12 \mathrm{~km} \cdot \mathrm{yr}^{-1}\right)$, higher in Romania $\left(48 \mathrm{~km} \cdot \mathrm{yr}^{-1}\right)$ and highest in Croatia and Serbia $\left(84 \mathrm{~km} \cdot \mathrm{yr}^{-1}\right)$.

In 2008, O. limosus was recorded in the Drava River, where it is spreading upstream from the Danube River. The mouth of the Drava River into the Danube River is less than $10 \mathrm{~km}$ downstream of the first record of spiny-cheek crayfish in Croatia; hence, it can be assumed that $O$. limosus reached the Drava River in the year 2003. Taking into account its current distribution front in the Drava River, which is $15 \mathrm{~km}$ upstream of the confluence with the Danube, the rate of upstream dispersal is less than $2.5 \mathrm{~km} \cdot \mathrm{yr}^{-1}$.

During the study period, populations of native narrow-clawed crayfish ( $A$. leptodactylus) were recorded in the Drava River and the Danube River (Figure 1). Both rivers represent the natural distribution range of $A$. leptodactylus. However, narrow-clawed crayfish were recorded in a lower number of sites than the invasive spiny-cheek crayfish. In the Drava River, species were found in mixed populations, which were dominated by O. limosus. In the Drava River, the ratio of CPUE between invasive and native species was 16:1 (Table III).

The calculations of NICS encounter area and time of encounter were based upon the assumption that species will continue to colonize the Drava River at the same dispersal rates. 


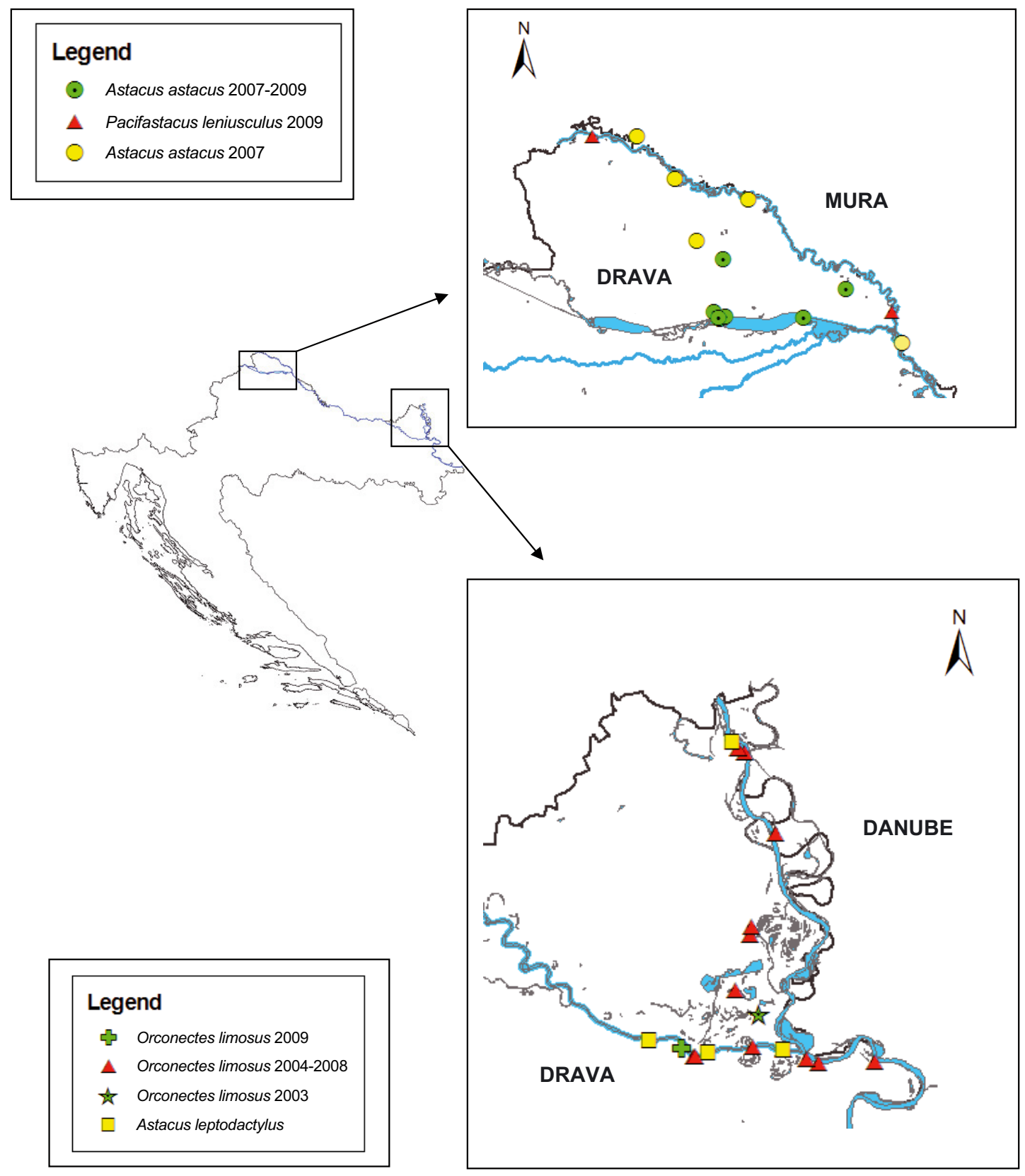

\section{Figure 1}

Distribution of the invasive signal crayfish and the native noble crayfish in the Drava and the Mura rivers, and distribution of the invasive spiny-cheek crayfish and the native narrow-clawed crayfish in the Drava and the Danube rivers.

Figure 1

Distribution de l'écrevisse signal invasive et de l'écrevisse à pattes rouges indigène dans les rivières Drava et Mura et distribution de l'écrevisse américaine invasive et de l'écrevisse à pattes grêles indigène dans la rivière Drava et le Danube. 
Table II

Overview of distribution data for spiny-cheek crayfish along the Danube River.

Tableau II

Bilan des données de distribution de l'écrevisse américaine dans le Danube.

\begin{tabular}{|c|c|c|c|c|c|c|c|c|c|}
\hline Year & Year & $\begin{array}{l}\text { Danube } \\
\text { kilometer }\end{array}$ & $\mathrm{km}$ & $\Delta$ years & $\Delta \mathrm{km}$ & $\mathrm{km} \cdot \mathrm{yr}^{-}$ & $\begin{array}{c}\text { Average } \\
\text { per region }\end{array}$ & Locality & Country \\
\hline 1985 & 0 & 1653 & 0 & & & & \multirow{4}{*}{12} & Budapest & Hungary \\
\hline 1991 & 6 & 1563 & 90 & 6 & 90 & 15 & & Dunaföldvár & Hungary \\
\hline 1998 & 13 & 1481 & 172 & 7 & 82 & 12 & & Gemenc & Hungary \\
\hline 2001 & 16 & 1450 & 203 & 3 & 31 & 10 & & Mohacs & Hungary \\
\hline 2002 & 17 & 1400 & 253 & 1 & 50 & 50 & \multirow{3}{*}{84} & Prigrevica & Serbia \\
\hline 2003 & 18 & 1388 & 265 & 1 & 62 & 62 & & Kopački rit & Croatia \\
\hline 2003 & 18 & 1260 & 393 & 1 & 140 & 140 & & Novi Sad & Serbia \\
\hline 2008 & 23 & 961 & 692 & 5 & 299 & 60 & 60 & Berzasca & Romania \\
\hline
\end{tabular}

\section{Table III}

CPUE in mixed populations of O. limosus and A. leptodactylus in the Drava River.

Tableau III

CPUE dans les populations mixtes d'O. limosus et $A$. leptodactylus dans la rivière Drava.

\begin{tabular}{|l|c|c|c|}
\hline Location & Date & $\begin{array}{c}\text { CPUE (individuals/trap/night) } \\
\text { Orconectes limosus }\end{array}$ & $\begin{array}{c}\text { CPUE (individuals/trap/night) } \\
\text { Astacus leptodacty/us }\end{array}$ \\
\hline Drava Sarvaš (mouth) & October 2008 & 1.97 & 0.123 \\
\hline Renovo Drava & October 2008 & 4.17 & 0.042 \\
\hline Renovo channel & October 2008 & 5.95 & 0.009 \\
\hline Renovo channel & September 2009 & 1.10 & 0.02 \\
\hline Nemetin Drava & September 2009 & 0.11 & 0 \\
\hline Nemetin channel & September 2009 & 0.22 & 0 \\
\hline
\end{tabular}

This suggests that signal crayfish would colonize a higher proportion of the Drava River, downstream of the Mura River mouth (rkm 236.7). The calculated encounter area would be $50 \mathrm{~km}$ from the Drava River mouth (into the Danube River), near the town of Belišće, and it would take 10 years for the two species to meet.

\section{> SIGNAL CRAYFISH (PACIFASTACUS LENIUSCULUS)}

The first record of the signal crayfish in Croatia dates from 2008 (Maguire et al., 2008). Until now, signal crayfish records in Croatia have been found only in the Mura River, where it is spreading downstream toward the confluence with the Drava River. In the extensive fieldwork performed during seven trapping events, signal crayfish distribution was recorded up to $3 \mathrm{~km}$ upstream of the river mouth (into the Drava River) (Figure 1), which is almost the whole Mura River length in Croatia $(75 \mathrm{~km})$.

The first and the most upstream record of $P$. leniusculus in the Slovenian part of the Mura River dates from 2003 (Bertok et al., 2003; Govedič, 2006; Veenvliet, 2006). In 2006 it was recorded downstream as far as the confluence with the Ščavnica River (Govedič, 2006), which is located one kilometer from the Croatian-Slovenian border. Taking into account the current recorded distribution limit and the most downstream record in Slovenia (river Ščavnica), downstream dispersal has been calculated at $18 \mathrm{~km} \cdot \mathrm{yr}^{-1}$. If the most upstream record in Slovenia (Slovenian-Austrian border) from 2003 is taken into account (Govedič, 2006) this rate increases to $24.4 \mathrm{~km} \cdot \mathrm{yr}^{-1}$. When compared with other rates of signal crayfish dispersal, recorded by different authors (Table IV), this rate is much higher than expected.

Catch per unit effort (CPUE) in the period of increased crayfish activity (August-October) at the most downstream site (Veliki Pažut, Figure 1) was on average 1 CPUE (crayfish/trap/night), 
Table IV

Signal crayfish dispersal speed data.

Tableau IV

Vitesse de dispersion de l'écrevisse signal.

\begin{tabular}{|l|c|c|c|c|}
\hline Authors & Year & Country & $\begin{array}{c}\text { Recorded dispersal } \\
\text { speed }\left(\mathrm{km} \cdot \mathrm{yr}^{-1}\right)\end{array}$ & Direction \\
\hline Holdich & 1995 & UK & 1 & downstream \\
\hline Peay & 1997 & UK & 1.27 & downstream \\
\hline Guan and Wiles & 1997 & UK & 1.1 & downstream and upstream \\
\hline Peay and Rogers & 1999 & UK & 1.2 & downstream \\
\hline Bubb et al. & 2005 & UK & 1.8 & downstream \\
\hline Bubb et al. & 2005 & UK & $0.35-0.47$ & upstream \\
\hline Dubois et al. & 2006 & France & $0.5-1$ & along shoreline \\
\hline Weinländer and Füreder & 2009 & Austria & $1.9-7$ & downstream \\
\hline Weinländer and Füreder & 2009 & Austria & $0.5-4$ & upstream \\
\hline
\end{tabular}

\section{Table $V$}

CPUE for P. leniusculus at the most upstream site (Sv. Martin) and the most downstream site Neliki Pažut) of its distribution in the Mura River.

\section{Tableau $\mathrm{V}$}

CPUE de P. leniusculus dans le site le plus en amont (Sv. Martin) et le site le plus en aval (Veliki Pažut) de sa distribution dans la rivière Mura.

\begin{tabular}{|l|c|c|}
\hline Location & Date & CPUE (individuals/trap/night) \\
\hline Mura - Sv. Martin & October 2008 & 4.86 \\
\hline Mura - Sv. Martin & August 2009 & 6.17 \\
\hline Mura - Sv. Martin & September 2009 & 4.29 \\
\hline \multicolumn{2}{|c|}{ Average } & $\mathbf{5 . 1 0}$ \\
\hline Mura - Veliki Pažut & September 2009 & 1 \\
\hline \multicolumn{2}{|c|}{ Average } & $\mathbf{1}$ \\
\hline
\end{tabular}

while at the most upstream site (Sv. Martin, Figure 1) it was 5.1 CPUE (Table V). During the fieldwork performed in 2008-2009, no noble crayfish were caught in the Mura River. However, literature data suggest that the noble crayfish was present at some of the examined localities in 2007. Noble crayfish populations have been recorded in the nearby Drava River watercourse, as well as in several surrounding channels and ponds (Figure 1). Within the trapping events in July and September 2009, 16 locations in the Drava River, upstream of the confluence with the Mura River, and 14 locations downstream of the confluence were inspected. No crayfish were recorded in the Drava River within these trapping events.

\section{DISCUSSION}

The occurrence of two NICS in Croatia is most probably the result of species dispersal along the Danube and the Mura rivers. Since crayfish are not regarded as a commercial item in the northern and eastern parts of Croatia, it is not likely that deliberate introductions of these species have occurred in Croatia. However, these events cannot be excluded as one of the possible means of NICS dispersal. Deliberate introductions are considered as one of the two most likely factors of the fast downstream spread of $O$. limosus along the Danube River (Puky and Schad, 2006; Puky, 2009). Also, as Puky and Schad (2006) argued, unknown translocations by boat traffic along the Danube River cannot be excluded as a possible introduction route for spiny-cheek crayfish. Boat traffic in the Danube River was given as a possible cause in the formation of an isolated population in the Ölhafen, in the south-eastern part of Vienna 
(Pöckl, 1999); therefore, this factor could have influenced the colonization of the Hungarian, Croatian, Serbian and Romanian parts of the Danube River by O. limosus.

The invasive spiny-cheek crayfish is present in the Croatian section of the Danube River where it spread from Hungary, and recently it has started its spread into the Drava River. The recorded dispersal rate in the Drava River $\left(2.5 \mathrm{~km} \cdot \mathrm{yr}^{-1}\right)$ is much lower than the literature records for the region (Puky and Schad, 2006), due to the dispersal direction (upstream). The comparison of CPUE for O. limosus in the main watercourse (the Drava River) and the adjacent channel (Renovo) shows that population density in the channel is two times higher than in the main watercourse (Table III). Apparently O. limosus uses the main watercourse (the Drava and the Danube rivers) for migration and dispersal, while it primarily inhabits channels where it establishes dense populations which form the basis for further dispersal. All of the O. limosus records in Croatia were found at altitudes of $100 \mathrm{~m}$, while in some European countries such as Switzerland, they were recorded as high as $800 \mathrm{~m}$ a.s.l. (Hefti and Stucki, 2006). As the Danube and the Drava rivers are at lower altitudes, the invasion has the potential to spread over the vast majority of water bodies in the Danube River catchment of Croatia.

In the Drava River O. limosus coexists with the native $A$. leptodactylus. In mixed populations, $O$. limosus exhibits higher population densities (approximately 16 times higher) than the native species; therefore, its impact on the river ecosystem may be stronger.

Signal crayfish records in the Slovenian and Croatian parts of the Mura River are considered to be the consequence of its spread from Austria where it was introduced in the 1970s (Pöckl, 1999; Pöckl and Pekny, 2002), and to date it has been recorded in at least 119 localities all over Austria (Pöckl, 1999). The downstream dispersal rate calculated from our data $\left(18-24.4 \mathrm{~km} \cdot \mathrm{yr}^{-1}\right)$ is very high compared with the results of other authors (Table IV). Among the analyzed literature data, the highest downstream dispersal rate was recorded in Austria at $7 \mathrm{~km} \cdot \mathrm{yr}^{-1}$ (Weinländer and Füreder, 2009), which is still 2.5 times lower than the values obtained in this study. The fast spread of the signal crayfish along the Mura River could perhaps be the consequence of hydrological conditions. The average discharge of the Mura River in Slovenia is $162 \mathrm{~m}^{3} \cdot \mathrm{s}^{-1}$, with the average annual maxima, in the period $1961-2005,658 \mathrm{~m}^{3} \cdot \mathrm{s}^{-1}$ and $646 \mathrm{~m}^{3} \cdot \mathrm{s}^{-1}$ at the upper and the lower sections of the Mura River, respectively (Globevnik and Mikloš, 2009). Changes in the water flow and sediment transport dynamics observed in the Mura River since the 1960s have been influenced by the construction of hydropower plants in the upper parts of the Mura River in Austria. Cumulative effects from extensive water abstractions and limited drainage of water in the river and tributary system resulted in an extensive lowering of the river bed and groundwater level, as well as an increased level of erosion (Globevnik and Kaligarič, 2005). With these hydromorphological changes, floods have almost doubled since the 1960s (Globevnik and Kaligarič, 2005). All the abovementioned aspects of hydrological changes, such as changes in the flow dynamics with high discharge peaks and frequent flooding, could potentially facilitate the fast dispersal rate of signal crayfish along the Mura River. The influence of flood events on crayfish downstream dispersal has been observed by several authors (e.g. Momot, 1966). On the other hand, the calculated high dispersal rate may also be the consequence of the undetected presence of signal crayfish in the Croatian part of the Mura before 2008 or Slovenian part of the Mura River before 2003. Lastly, human interference (deliberate introductions) cannot be excluded as a possible explanation of the recorded fast range expansion.

Signal crayfish population densities are high at the most upstream sites in the Croatian part of the Mura River (5.1 CPUE), and entirely dominated by this species. No noble crayfish have been caught since 2007 in any section of the Mura River. These data are still not sufficient to confirm that the noble crayfish has been displaced from the Mura River in Croatia, although research in other countries shows that replacement of the native by the invasive crayfish can take place. In many water bodies of Austria, replacement of the noble crayfish by the signal crayfish has been recorded in a period of 4-5 years (Pöckl, 1999). In Germany, a slow upward displacement of the stone crayfish, Austropotamobius torrentium, by plague-free signal crayfish was observed (Huber and Schubart, 2005). No impact of signal crayfish has yet 
been observed on stone crayfish populations in the tributaries of the Mura River in Slovenia (Govedič, pers. comm.).

The noble crayfish populations are still numerous in the side channels and ponds between the Mura River and the Drava River. Pond populations were mainly formed by deliberate introductions by local fishermen approximately 20 years ago. Signal crayfish populations have not been recorded in any of the ponds yet. These ponds are isolated and maintain stable noble crayfish populations as no crayfish trapping occurs in this area. Isolated populations of ICS have an increasing importance as refuge sites and potential pools of genetic diversity for repopulation in the future. Therefore, ponds between the Mura River and the Drava River could represent possible sites for native noble crayfish conservation in the Drava River basin. Calculated species dispersal rates for both NICS were based upon the assumption that the last NICS record (the most downstream in the case of $P$. leniusculus in the Mura River, and the most upstream in the case of $O$. limosus in the Drava River) represents the distribution front. However, as trapping activities are biased towards larger specimens (Hogger, 1988; Price and Welch, 2009) it is very likely that the actual distribution front has not been precisely located, because population densities at the front will be very low and possibly dominated by smaller individuals.

The calculated encounter area in the Drava River and timing (10 years from now, at rkm 50) are very speculative as they presume the same dispersal rate for signal crayfish in the Drava River as in the Mura River, which is highly unlikely due to differences in hydrological regimes and other environmental characteristics. Also, this calculation does not take into account the influence of human facilitation of dispersal through intentional or unintentional introductions on the calculated and predicted dispersal values.

\section{CONCLUSION}

Two NICS recorded in the Drava River catchment are experiencing a fast expansion rate. The fast downstream dispersal rate of the signal crayfish in the Mura River is in agreement with the rates of downstream dispersal of spiny-cheek crayfish in the Danube catchment. The fast range expansion of these two species in large rivers was recorded by several authors who consider it as a consequence of either undefined biological or ecological factors or human interference. Regardless of the exact cause, it seems that large rivers of the Black Sea drainage system represent an important corridor for fast downstream dispersal of invasive crayfish. In the Drava River catchment, the crayfish fauna could become completely dominated by two NICS if no management activities are put into action. Finally, due to the speed and intensity of dispersal, the invasion in the Drava river catchment has the potential to spread in the vast majority of water bodies in NE Croatia.

\section{ACKNOWLEDGEMENTS}

We would like to thank Tomislav Devčić, Mišo Rašan and his students, Krešimir Žganec and Jasna Lajtner, who helped us during the fieldwork. Also, we appreciate very much the support from the Siniša Golub and the Public Institution for Nature Protection of Medimuje County and Hrvoje Domazetović from the Nature Park Kopački rit. This research is funded by the Ministry of Science Education and Sports (research project 119-1193080-1231), Directorate for Nature Protection of Ministry of Culture, State Institute for Nature Protection and Croatian Waters. Finally, we want to thank Nika Galić and the two unknown referees for their comments and improvements on the earlier version of the manuscript.

\section{REFERENCES}

Bern Convention. http://conventions.coe.int/Treaty/EN/Treaties/Html/104.htm, Accessed September 2009. 
Bertok M., Budihna N. and Povž M., 2003. Strokovne osnove za vzpostavljanje omrežja Natura 2000 Ribe (Pisces), Piškurji (Cyclostomata), raki deseteronožci (Decapoda). Zavod za ribištvo, Ljubljana, $371 \mathrm{p}$.

Bubb D.H., Thom T.J. and Lucas M.C., 2005. The within-catchment invasion of the non-indigenous signal crayfish Pacifastacus leniusculus (Dana), in upland rivers. Bull. Fr. Pêche Piscic., 376-377, 665-673.

Diéguez-Uribeondo J. and Söderhäll K., 1993. Procambarus clarkii Girard as a vector for the crayfish plague fungus, Aphanomyces astaci Schikora. Aquacult. Fish. Manage., 24, 761-765.

Dubois J.P., Gillet V. and Michoud M., 2006. Extension d'une espèce envahissante : suivi de la population d'écrevisse signal (Pacifastacus leniusculus Dana) au Léman à l'ouest de Thonon-les-Bains, entre 2001 et 2005 - Impact de la pêche. Bull. Fr. Pêche Piscic., 382, 45-56.

Globevnik L. and Kaligarič M., 2005. Hydrological changes of the Mura River in Slovenia accompanied with habitat deteoration in the riverine space. RMZ - Materials and Geoenvironment, 52, 1, 45-49.

Globevnik L. and Mikloš M., 2009. Boundary conditions of morphodynamic processes in the Mura River in Slovenia. Catena, 79, 265-276.

Govedič M., 2006. Potočni raki Slovenije : razširjenost, ekologija, varstvo. Center za kartografijo favne in flore, Miklavž na Dravskem polju, 15 p.

Govedič M., Bedjanič M., Grobelnik V., Kapla A., Kus Veenvliet J., Šalamun A., Veenvliet P. and Vrezec A., 2007. Dodatne raziskave kvalifikacijskih vrst Natura 2000 s predlogom spremljanja stanja - raki. Center za kartografijo favne in flore, Miklavž na Dravskem polju, $128 \mathrm{p}$.

Guan R.-Z. and Wiles P.R., 1999. Growth and reproduction of the introduced crayfish Pacifastacus leniusculus in a British lowland river. Fisheries Research, 42, 245-259.

Hefti D. and Stucki P., 2006. Crayfish management for Swiss waters. Bull. Fr. Pêche Piscic., 380-381, 937-950.

Hobbs H.H. III, Jass J.P. and Huner J.V., 1989. A review of global crayfish introductions with particular emphasis on two North American species (Decapoda, Cambaridae). Crustaceana, 56, 299-316.

Hogger J.B., 1988. Ecology, population biology and behaviour. In: Holdich D.M. and Lowery R.S. (eds.), Freshwater crayfish: Biology, Management and Exploitation, The University Press, Cambridge, 114-144.

Holdich D.M., 2002. Distribution of crayfish in Europe and some adjoining countries. Bull. Fr. Pêche Piscic., 367, 611-650.

Holdich D.M. and Pöckl M., 2007. Invasive crustaceans in European inland waters. In: Francesca Gherardi (ed.), Biological invaders in inland waters: Profiles, distribution, and threats, Springer, 29-75.

Holdich D.M. and Rogers W.D., 1995. Crayfish survey of the River Wharfe, University of Nottingham.

Huber M.G.J. and Schubart C.D., 2005. Distribution and reproductive biology of Austropotamobius torrentium in Bavaria and documentation of a contact zone with the alien crayfish Pacifastacus leniusculus. Bull. Fr. Pêche Piscic., 376-377, 759-776.

Karaman I. and Machino Y., 2004. Occurrence of the spiny-cheek crayfish (Orconectes limosus) and the Chinese mitten crab (Eriocheir sinensis) in Serbia. Crayfish news, 26, 2, 19-20.

Lodge D.M., Kershner M. and Aloi J., 1994. Effects of and omnivorous crayfish (Orconectes rusticus) on a freshwater littoral food web. Ecology, 15, 5, 1265-1281.

Lodge D.M., Stein R.A., Brown K.M., Covich A.P., Bronmark C., Garvey J.E. and Klosiewski S.P., 1998. Predicting impact of freshwater exotic species on native biodiversity: challenges in spatial scaling. Aust. J. Ecol., 23, 53-67.

Lodge D.M., Taylor C.A., Holdich D.M. and Skurdal J., 2000. Nonindigenous crayfishes threaten North American freshwater biodiversity: Lessons from Europe. Fisheries, 25, 7-20.

Machino Y., Füreder L., Laurent P.J. and Petutschnig J., 2004. Introduction of the white-clawed crayfish Austropotamobius pallipes in Europe. Ber. naturwiss.-med. Verein Innsbruck, 91, 187-212.

Maguire I. and Gottstein-Matočec S., 2004. The distribution pattern of freshwater crayfish in Croatia. Crustaceana, 77, 1, 25-49.

Maguire I. and Klobučar G.I.V., 2003. Appearance of Orconectes limosus in Croatia. Crayfish news, 3, $25,7$.

Maguire I., Klobučar G.I.V., Marčić Z. and Zanella D., 2008. The first record of Pacifastacus leniusculus in Croatia. Crayfish news, 30, 4, 4. 
Momot W.T., 1966. Upstream movement of crayfish in an intermittent Oklahoma stream. Am. Midl. Nat., $75,1,150-159$.

Narodne Novine, $70 / 05$ \& 139/08. Nature Protection Act (70/05) and the changes in the Nature Protection Act (139/08).

Pârvulescu L., Paloş C. and Molnar P., 2009. First record of the spiny-cheek crayfish Orconectes limosus (Rafinesque, 1817) (Crustacea: Decapoda: Cambaridae) in Romania. North-West. J. Zool., 5, 2, 424-428.

Pavlović S., Milošević S., Borković S., Simić V., Paunović M., Žikić R. and Saičić Z., 2006. A report of Orconectes (faxonius) limosus (Rafinesque, 1817) [Crustacea: Decapoda: Astacidea: Cambaridae: Orconectes: Subgenus Faxonius] in the Serbian Part of the River Danube. Biotechnol. Biotechnol. Eq., 20, 53-56.

Peay S., 1997. Night survey for crayfish in the River Wharfe, Yorkshire. Master's Thesis, University of Hull, 120 p.

Peay S. and Rogers D., 1999. The peristaltic spread of signal crayfish (Pacifastacus leniusculus) in the River Wharfe, Yorkshire, England. Freshwater Crayfish, 12, 665-676.

Pöckl M., 1999. Distribution of crayfish species in Austria with special reference to introduced species. Freshwater Crayfish, 12, 733-750.

Pöckl M. and Pekny R., 2002. Interaction between native and alien species of crayfish in Austria: case studies. Bull. Fr. Pêche Piscic., 367, 763-776.

Price J.E. and Welch S.M., 2009. Semi-quantitative methods for crayfish sampling: Sex, size, habitat bias. J. Crustacean Biol., 29, 2, 208-216.

Puky M., 2009. Status and distribution of invasive crayfish species in Hungary: Pacifastacus leniusculus colonises the western and south-western region, Orconectes limosus spreads along Danubian tributaries. Proceedings of the Regional European Crayfish Workshop: Future of Native Crayfish in Europe, Pisek, 53.

Puky M. and Schád P., 2006. Oronectes limosus colonizes new areas fast along the Danube in Hungary. Bull. Fr. Pêche Piscic., 380-381, 919-926.

Puky M., Reynolds J.D. and Schád P., 2005. Native and alien decapoda species in Hungary: distribution, status, conservation importance. Bull. Fr. Pêche Piscic., 376-377, 553-568.

Ricciardi A., 2001. Facilitative interactions among aquatic invaders: is an 'invasional meltdown' occurring in the Great Lakes? Can. J. Fish. Aquat. Sci., 58, 2513-2525.

Sala O.E., Chapin F.S. III and Armesto J.J., 2000. Global biodiversity scenarios for the year 2100. Science, 287, 1770-1774.

Sallai Z. and Puki M., 2008. A cifrarák (Orconectes limosus) megjelenése a Közép-Tisza-Vidékén. Acta Biologica Debrecina Supplementum Oecologica Hungarica, 18, 203-208.

Souty-Grosset C., Holdich D.M., Noel P.Y., Reynolds J.D. and Haffner P. (eds.), 2006. Atlas of crayfish in Europe, Muséum national d'Histoire naturelle, Paris, $187 \mathrm{p}$.

Statzner B., Peltret O. and Tomanova S., 2003. Crayfish as geomorphic agents and ecosystem engineers: effect of a biomass gradient on baseflow and flood-induced transport of gravel and sand in experimental streams. Freshwater Biol. , 48, 147-163.

Usio N. and Townsend C.R., 2002. Functional significance of crayfish in stream food webs: roles of omnivory, substrate heterogeneity and sex. Oikos, 98, 512-522.

Veenvliet P., 2006. Signalni raki so v Sloveniji. Kaj lahko storimo? Ribič, Ljubljana, 50, 1-2, 983.

Weinländer M. and Füreder L., 2009. The continuing spread of Pacifastacus leniusculus in Carinthia (Austria): potential reasons, invasiveness and ecological effects, Proceedings of the Regional European Crayfish Workshop: Future of Native Crayfish in Europe, Pisek, 53.

Westman K., Pursiainen M. and Vilkman R., 1978. A new folding trap model which prevents crayfish from escaping. Freshwater Crayfish, 4, 235-242.

WWF, 2009. Mura-Drava-Danube Transboundary Biosphere reserve, Croatian-Hungarian Declaration, $2 \mathrm{p}$. 